\title{
The Utilization of Metroxylon sago Dregs for Eco-friendly Bioethanol Stove in Papua, Indonesia
}

\author{
I Made Kartika Dhiputra ${ }^{\mathrm{a}}$, Numberi Johni Jonatan ${ }^{\mathrm{a} *}$ \\ ${ }^{a}$ Flame and Combustion Research Group, Laboratory of Thermodynamics, Faculty of Engineering, University of Indonesia.
}

\begin{abstract}
Indonesia's dependency on fossil energy is relatively high; approximately $55 \%$ fuel oil that comes from fossil is used in the household sector. The increasing of energy demand is not supported by the energy availability. This issue prompted the government of Indonesia to develop a diverse, cheaper, renewable, sustainable and eco-friendly alternative energy and to create an independent management which ensures the availability of energy to people in remote area. Among other possible solution, production of bioethanol from Metroxylon sago dregs as alternative energy resources is considered as the most feasible solution. Indonesia has $\pm 1,250,000$ billion ha of sago plantation and in Papua there is $\pm 1,200,000$ billion ha of land with sago potential, of which only $56 \%$ is used. Research methods include fermentation of sago dregs to become bioethanol, its distillation process and flame characteristics. Results of laboratory experiment showed that sago dregs are viable as a source of fuel bioethanol because it still contains $82.4 \%$ vol. of carbohydrate component. Measurement of flame temperature on bioethanol burner with ethanol content of 60 to $95 \%$ is strongly influenced by these parameters: turbulence, temperature, mixing time and the rest of the air-fuel flow.
\end{abstract}

Keywords: bioethanol; flame characteristics; Metroxylon sago dregs

\begin{tabular}{|ll|}
\hline Nomenclature & \\
$\mathbf{A}$ & $=$ Area flame $\left(\mathrm{m}^{2}\right)$ \\
$\mathbf{B L}$ & $=$ Burning load $\left(\mathrm{kW} / \mathrm{m}^{2}\right)$ \\
$\mathbf{H V}$ & $=$ Heating value $(\mathrm{joule} / \mathrm{kg})$ \\
$\dot{\mathbf{m}}_{\mathbf{f}}$ & $=$ Fuel mass flow $(\mathrm{kg} / \mathrm{s})$ \\
$\mathbf{C}_{6} \mathbf{H}_{10} \mathbf{O}_{5}$ & $=$ Carbohydrate \\
$\mathbf{H}_{2} \mathbf{O}$ & $=$ Water \\
$\mathbf{C}_{6} \mathbf{H}_{12} \mathbf{O}_{6}$ & $=$ Glucose \\
$\mathbf{C}_{2} \mathbf{H}_{5} \mathbf{O H}$ & $=$ Ethanol \\
\hline
\end{tabular}

\footnotetext{
* Corresponding author. Tel: 021727 0032; or HP: 0828266 036, fax: 0217270033

E-mail address:dhiputra_made@yahoo.com
} 


\section{Introduction}

Metroxylon sago is one of Indonesia's native plants that can be used as energy source to produce bioethanol, which can be mixed with fuel oil and, in certain circumstances, can be used directly - without prior mixing with other fuel - as fuel in stoves for domestic use in rural area which is unreachable by the distribution of fuel oil. The example of such area is Papua, the easternmost province of Indonesia. As a province, Papua, consisting of 28 regencies and one city, is astronomically located at $2^{\circ} 25^{\prime}-9^{\circ} \mathrm{SL}$ and $134^{\circ}-141^{\circ}$ EL with a total area of 317.062 $\mathrm{km}^{2}$ or about $22.08 \%$ of Indonesia's total area (BPS Papua Province, 2013). This province has a population of 2,097,482 people and the population growth rate of $2.53 \%$ to $5.54 \%$.Topographic distribution of the population in Papua is uneven, making it difficult to build infrastructure to support activities of the community.

As an example, because of the geographical obstacle, it is extremely hard to distribute Pertamina fuel oil by land, sea and air from fuel depots in Jayapura and Sorong. Renewable energy developmentcanbe viewed as a solution in such areas according topotentialbiofuel resources, especiallybioethanol. This study is also in accordance with the national policy of Indonesia's government in addressing the energy crisis: Presidential instruction No. 1 issued in 2006 regarding the provision and use of biofuel, Presidential regulation No. 5 issued in 2006 regarding the national energy policy, as well as Presidential decree No.10 issued in 2006 on the national team for the development of biofuel to accelerate poverty reduction and unemployment. Indonesia has $\pm 1,250,000$ billion ha of sago plantation and in Papua there is $\pm 1,200,000$ billion ha of land with sago potential.

Table.1 Area of sago plantation in the world.

\begin{tabular}{|c|c|c|c|c|c|c|}
\hline Country & Natural sago (ha) & $\begin{array}{l}\text { Sago } \\
\text { cultivation (ha) }\end{array}$ & $\begin{array}{l}\text { Indonesia's } \\
\text { Island }\end{array}$ & $\begin{array}{l}\text { Natural } \\
\text { (ha) }\end{array}$ & sago & $\begin{array}{l}\text { Cultivation of } \\
\text { sago } \\
(\mathrm{Ha})\end{array}$ \\
\hline Indonesia & $1,250,000$ & 148,000 & Papua & $1,200,000$ & & 14,000 \\
\hline Papua New Guinea & $1,000,000$ & 20,000 & Maluku & 500,000 & & 10,000 \\
\hline Malaysia & & 45,000 & Celebes & & & 30,000 \\
\hline Thailand & & 3,000 & Borneo & & & 20,000 \\
\hline The Philippines & & 3,000 & Sumatra & & & 50,000 \\
\hline Other countries & & 5,000 & Mentawai & & & 20,000 \\
\hline Total & $2,250,000$ & 224,000 & Total & $1,250,000$ & & 148,000 \\
\hline
\end{tabular}

Source: Freddy Numberi, 2010.

\section{Material and method}

Based on a literature study of the road map, the planned research can be described in Figure 1. 


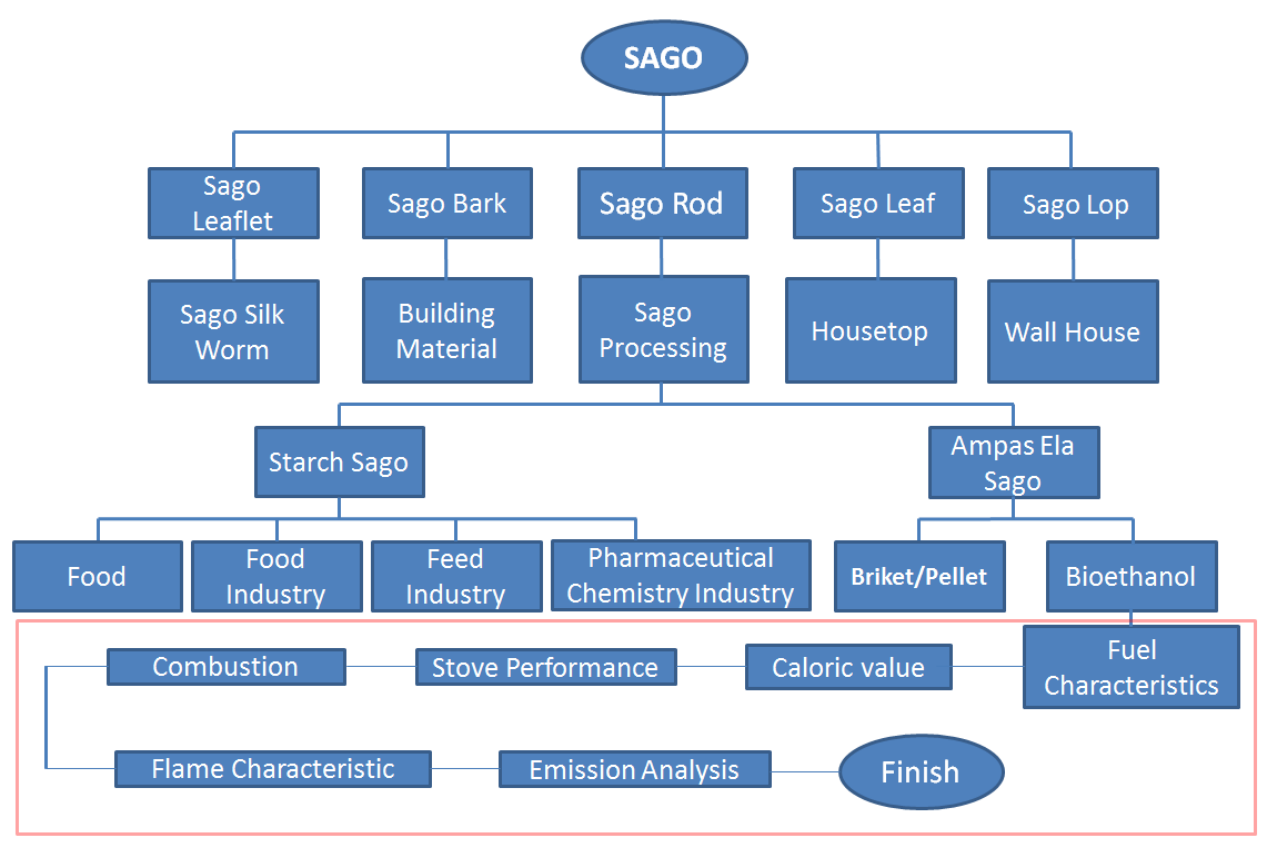

Figure 1. Road map research.

\subsection{Physical pre-treatment.}

Pre-treatment process is done through some series of physical-mechanical methods. The steps in the research process are acquiring the sago dregs from the community of sago industry, drying with sunlight for three days, and cutting of dried sago dregs. The term pre-treatment in this case is the separation process of lignocellulose by means of physical-mechanical methods, which use cutter mill and hammer mill for smoothing sago dregs, to get smoother dregs that can pass a series of filtration with certain mesh requirement. The sizes of mesh that is used in this process are 60; 100 and 150, which are used gradually from the less smooth to which that results into powder-like dregs. The dregs are then analysed by using proximate analysis and photo of SEM EDS.

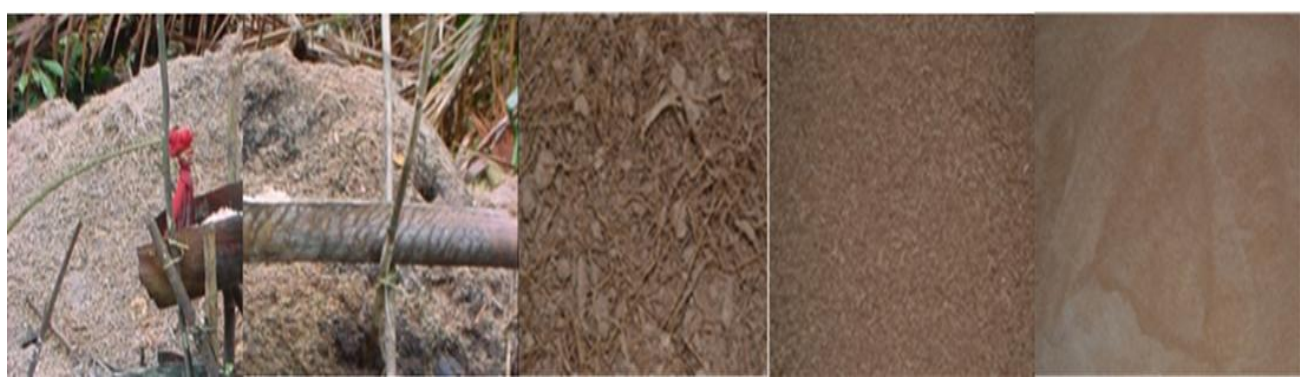

Figure 2. Mechanical pre-treatments on the waste of dregs sago passed 150 mesh. 


\subsection{Characterization}

Scanning by using Electron EDX microscopic is done to observe the structure of the hydrocarbon component of ordinary Papuan sago dregs in the conversion to bioethanol.

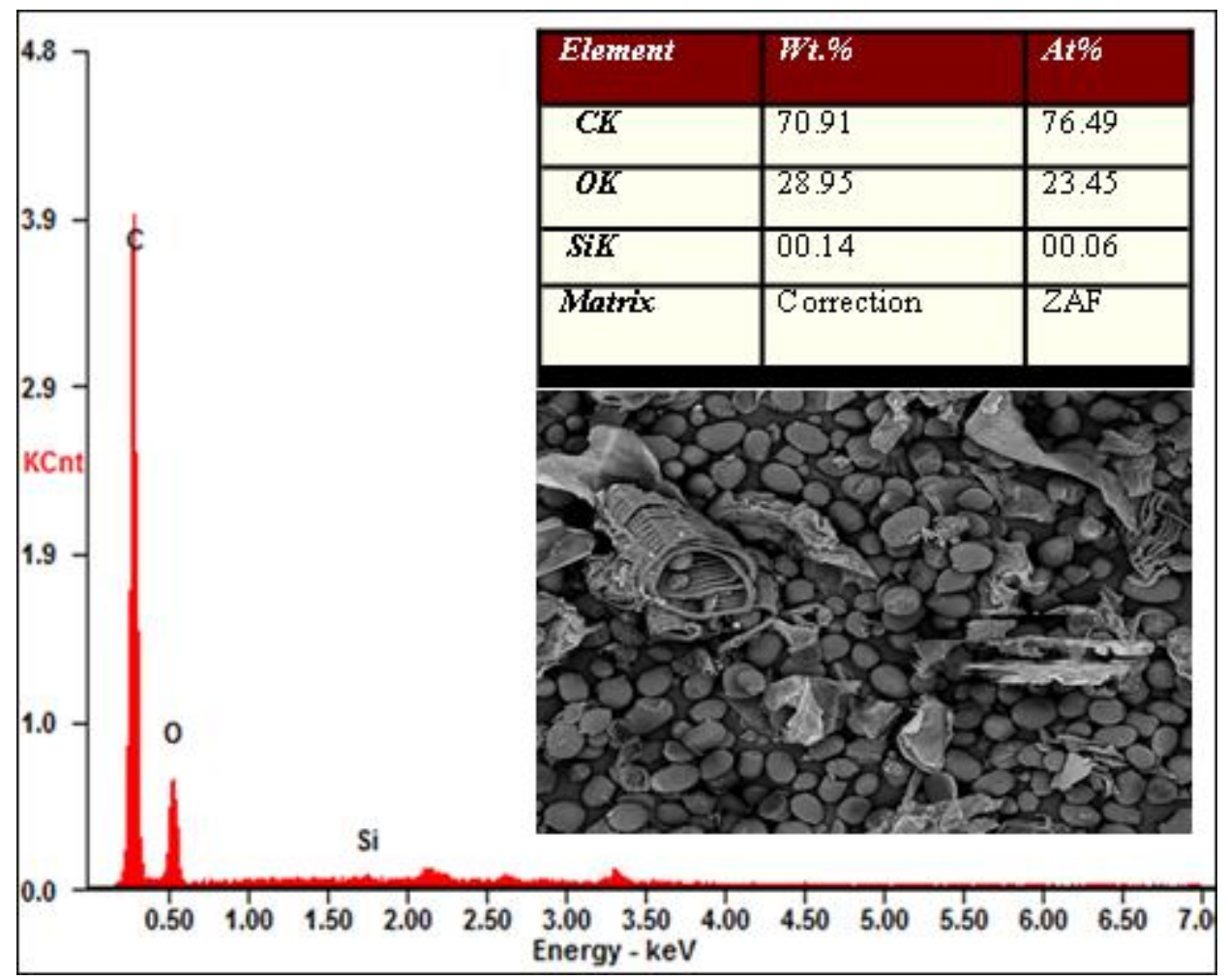

Figure 3. The forms of characterization sago dregs.

The results from scanning electron microscopic (SEM EDX) analysis showed that $76.49 \%$ of sago dregs is structural carbon, that can be converted into bioethanol. That percentage consists of fibre, glycerol and also lignocellulose that contain much cellulose and sago starch.

Characterization of sago dregs showed that the content of cellulose and carbohydrates can be optimally used as an energy source in bioethanol.

Table 2. Composition sago dregs

\begin{tabular}{ll}
\hline $\begin{array}{l}\text { Physical colour } \\
\text { Test Parameters }\end{array}$ & $\begin{array}{l}\text { Brownish } \\
\text { Percentage Composition }\end{array}$ \\
\hline water content & $16.3 \%$ \\
Ash & $0.50 \%$ \\
Protein & $0.80 \%$ \\
fat & $0.01 \%$ \\
Carbohydrate & $82.4 \%$ \\
crude fibres & $1.67 \%$ \\
\hline
\end{tabular}


The characterization results showed that the sago dregs contained $82.4 \%$ carbohydrate sago, implicating that it is feasible to process sago dregs into bioethanol. Sago dregs are hydrolysed into glucose by alpha-amylase and amyglukosa enzyme. After that, the glucose is fermented by yeast (Saccharomyces) to produce ethanol. These following reactions show the production of bioethanol from sago dregs.

$\begin{array}{llll}\left(\mathrm{C}_{6} \mathrm{H}_{10} \mathrm{O}_{5}\right) & + & \mathrm{H}_{2} \mathrm{O} & a-\text { Amylase } \\ \text { sago dregs } & \rightarrow & 2 \mathrm{C}_{6} \mathrm{H}_{12} \mathrm{O}_{6} \\ \text { water } & & \text { glucose }\end{array}$

\begin{tabular}{ccc}
\multicolumn{4}{c}{ Saccharomyces } \\
$\begin{array}{c}\mathrm{C}_{6} \mathrm{H}_{12} \mathrm{O}_{6} \\
\text { glucose }\end{array}$ & $\rightarrow$ & $\begin{array}{l}\mathrm{C}_{2} \mathrm{H}_{5} \mathrm{OH} \\
\text { ethanol }\end{array}$
\end{tabular}

2.3. Experimental set-up for research of bioethanol flame and combustion in eco-friendly stove.

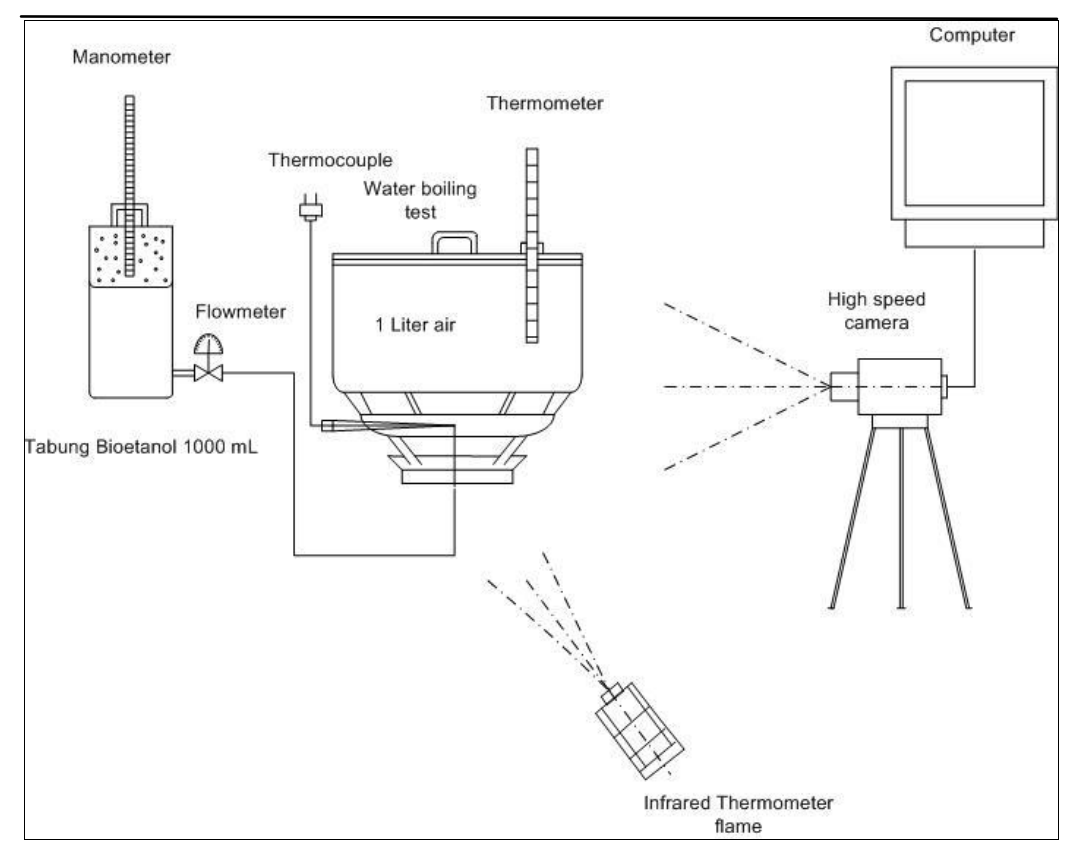

Figure 5. Experimental set-up research fireflame.

Experimental characteristics of flame on a bioethanol stove was done at Laboratory of Thermodynamics, Department of Mechanical Engineering, Faculty of Engineering, University of Indonesia using a bioethanol stove and ethanol with concentration of $60 \%$ to $90 \%$. The objective is to observe the flame stability phenomena. Experiments carried out by setting the flow rate of fuel was measured by flow meter. Burning Load (BL) is calculated by using the following equation.

$$
B L=\frac{m \times H V}{A}
$$


In equation $2, \mathrm{BL}$ is the load of combustion 1.1. $\left[\mathrm{kW} /, \mathrm{A}\right.$ is total burner cross-sectional area $\left[\mathrm{m}^{2}\right]$ and $\mathrm{HV}$ is the calorific value of the fuel [Joule $/ \mathrm{kg}$ ]. The flame stability was captured by using a high speed camera and infrared thermometer that were connected to the computer to measure the temperature on the surface. The length of flame was also measured using a steel bar as a reference comparison. Flame temperature measurement was also performed by using a type $\mathrm{K}$ thermocouple. The flame stability, as a function of flow rate of air and fuel was measured by infrared thermometer, while the flow rate of fuel in the fuel pipe system was measured by flow meter.

\section{Results and discussion}
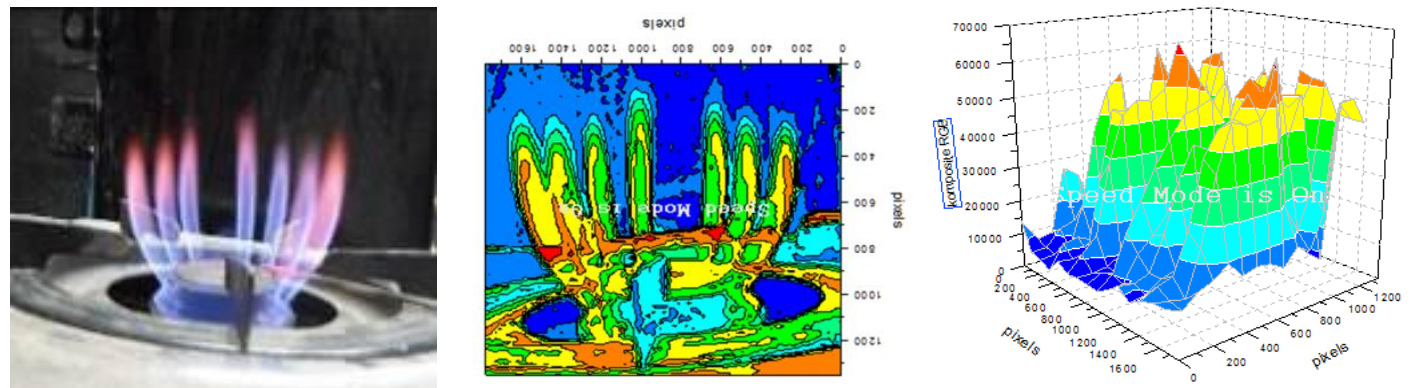

Figure 6.The phenomena of bioethanol fire flame of sago dregs.

Based on the experiment of the characteristics of the pre-heating zone of bioethanol, the start-up occurred in $60 \mathrm{~s}$, before it produced a stable flame for $300 \mathrm{~s}$. The characteristics of flame depend on the variety of the burning load and the evaporation time of fuel in order to produce the 'flame jet' phenomena on the stove

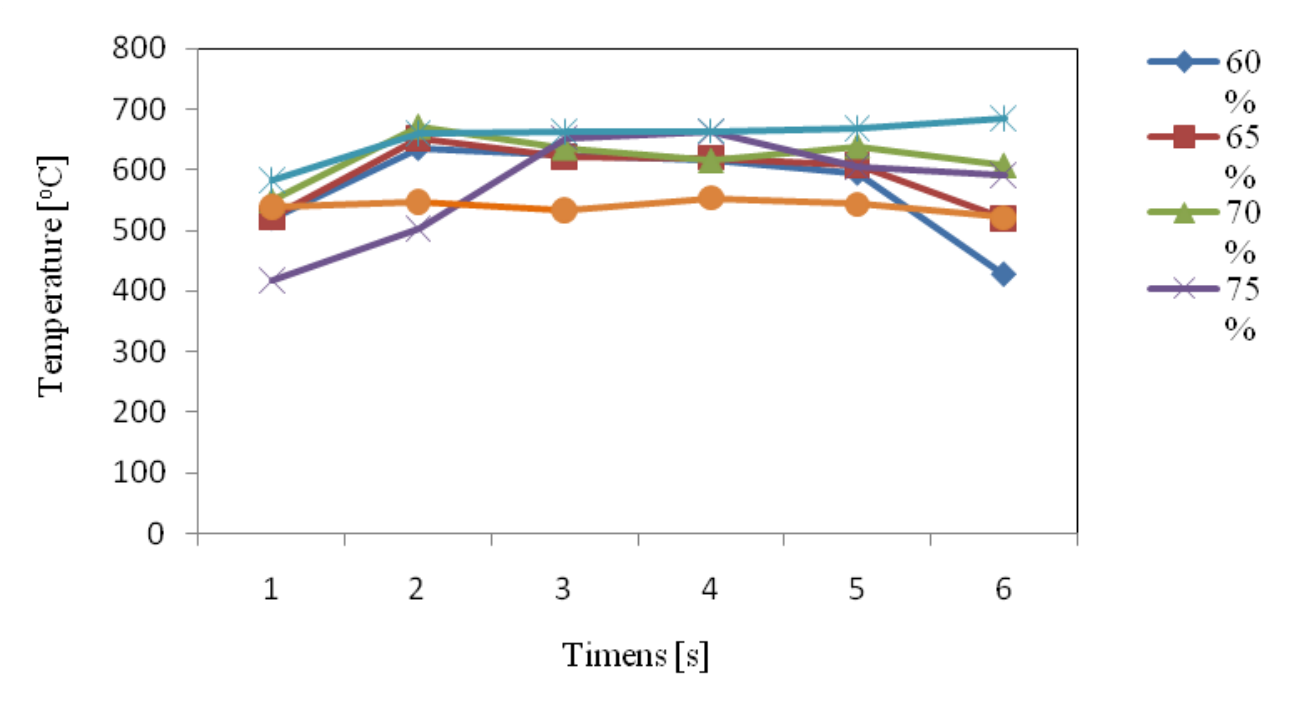

Figure 7. Characteristics of bioethanol flame dregs sago. 


\section{Conclusion}

The experiment produced a luminous flame from bioethanol burning with a concentration of $80 \%$ produced the most stable flame and the diffusion flame characteristics of jet flame, which came out from each hole, is very homogenous.

\section{References}

[1] Department of Energy and bio -fuel mineral resources. The collections of rules about vegetable fuel program; 2006

[2] Chen, J. X.F. Peng, Z. L. yamg, J. Cheng. Characteristics of liquid ethanol diffusion flame nozzle tube mini. Tsinghua University, Beijing, China; 2008.

[3] Flach, M . Sago metroxylon Rottb. IPGRI. Rome; 1997.

[4] Haška, N. Sago utilization potential and opportunities for food ingredients, raw energy and national industri.seminar sago in prospects of national food security and energy. University Club Yogyakarta; 22 November 2008.

[5] Dhiputra I Made Kartika, MahandariCokordaPrapti, SitinjakAmriParlindungan, SugiartoBambang. Effect of material of flame hold ring in flame lift-up phenomena. Flame and combustion research group, Laboratory of Thermodynamics, Department of Mechanical Engineering, Faculty of Engineering, University of Indonesia. Journal of mechanical engineering; 2012.

[6] Dhiputra I Made Kartika, \&NumberiJohniJonatan. Physical-chemical characteristics of sago dregs as bioethanol fuel. Laboratory of Thermodynamics, Department of Mechanical Engineering, Faculty of Engineering University of Indonesia.Journal SNF LIPI Serpong; 2013.

[7] Kasper, T.S., P. Osswald, M. Kamphus. K. Kohse-Höinghaus. Ethanol flame structure investigated by molecular beam mass spectrometry.Universität Bielefeld, Universitatsstrasse, Germany; 2006.

[8] Numberi, F. Potencial sago is neglected. The popular science bhuana. Jakarta; 2010. 